Research Article

\title{
Indonesia Tax Authority Measure on Facing the Challenge in Taxing Digital Economy
}

\author{
Maria R.U.D. Tambunan*, Haula Rosdiana \\ Department of Fiscal Administrative Science, Universitas Indonesia, Depok, West Java 164246, Indonesia
}

\section{ARTICLE INFO}

Article History

Received 06 December 2019

Accepted 19 December 2019

Keywords

Taxation

digital economy

e-commerce

\begin{abstract}
This article is intended to examine the challenges of taxing digital economy due to rapid development of technology in Indonesia. Those changes should be responded equally from the government perspective pertaining to the changes in tax regulation, structure/institutional of tax organization, human resources who understand the pattern and development of digital business and have capability to formulate tax regulation suitable for the business pattern, and information technology reliable in transforming the business of the tax organization. This study occupies constructivism paradigm and qualitiative research method. The data was gathered through literature review, documentation study and interview with informant. The research showed that for all of those aspects, the Indonesian government has realized that the change is very crucial. The government of Indonesia also fully realizes that the rapid development of the economic activities and should respond it by publishing various proper regulations and initiatives. However, some of the regulations are still insufficient to respond to the existing challenges. This indicates that in reality, the government is still unable to respond to the current dynamic properly and proportionally. Organization changing on the context of bureaucracy reform also still on the progress, similarly on the development of human resources capacity and the use of technology to optimize tax collection effort. Therefore, more comprehensive improvement through engagement of various agents to properly respond to the current economic development is essentially required.
\end{abstract}

(C) 2020 The Authors. Published by Atlantis Press International B.V.

This is an open access article distributed under the CC BY-NC 4.0 license (http://creativecommons.org/licenses/by-nc/4.0/).

\section{INTRODUCTION}

Economic activities pattern is currently growing exponentially and very dynamic as a result of technology penetration into each activity line. Nowadays, business activity has become mobile and even intangible, where the physical form of a business entity is unnecessary and business unit or each value chain of a corporate entity is becoming more integrated ([1]; p. 9). This depicts a very different situation to the traditional concept or closed economy, "brickand mortar business", where a country's jurisdiction influences the business entity activities pattern ([2]; p. 13). OECD Observer [3] stated that digitalization cannot be controlled by "ring-fence". This phenomenon is the impact of the fourth industrial revolution (Industry 4.0) with technology innovation serves as the backbones, allowing the rapid growth of various new business models and disruptive impact to the traditional economic patterns [4].

Schön ([5]; p. 1) also stated that in the context of the reformation of the international tax, the existence of the digital era becomes one of the most important factors to be considered. There are at least two assumptions concerning this that are still debatable:

a. Digitalization allows each individual to sell goods and services to anywhere without the requirement to build a physical entity

Corresponding author.Email: maria.tambunan@ui.ac.id (in the form of permanent establishment) or subsidiary in the jurisdiction of the market country.

b. The business model built by most business entities that have been successful in the digital era is gained from the intangible asset (patent, algorithm). Relating to the multinational companies economics of scale, these entities prefer particular jurisdiction as a central to run their economic function and value chain activities, then designing the jurisdiction location, which then becomes the center of consumers and the jurisdiction where the patent right originated.

OECD (Organisation for Economic Co-operation and Development) also realized that the massive digitalization also has an impact to the taxation aspect, where each government has to build coordination to tackle the issue of profit shifting on this phenomenon, since the old taxation pattern was unable to follow the rapid business development. OECD [6] has designated a map of various types of income from various digital economic activities as described in Table 1.

Pertaining to the changes in the business models, OECD has formulated various strategies by publishing 15 Base Erosion and Profit Shifting (BEPS) Action Plan to deal with tax base erosion and profit shifting, particularly on Action 1, concerning the taxation on digital economic activities. This regulation is aimed to reach an international tax consensus on the taxation pattern adaptable to the 
Table 1 Various types of incomes from digital economic activities

\begin{tabular}{|c|c|c|}
\hline No. & Types of income & Description \\
\hline 1 & $\begin{array}{l}\text { Advertising-based } \\
\text { revenue }\end{array}$ & $\begin{array}{l}\text { This type of income is received from various business models, such as digital content provisions in the form of paid adver- } \\
\text { tising space on a website or platform (application) that can be accessed from the internet. Mostly this type of commer- } \\
\text { cial advertisement is delivered by social media platform. }\end{array}$ \\
\hline 2 & $\begin{array}{l}\text { Digital content } \\
\text { purchase or rent }\end{array}$ & $\begin{array}{l}\text { Digital content provisions by a transaction on each download, such as selling of e-book, online news subscription, video } \\
\text { clip, music, online game application and other digital items. }\end{array}$ \\
\hline 3 & Selling of goods & $\begin{array}{l}\text { Online retailers, which sell tangible goods through their official websites or online marketplace on the internet and the } \\
\text { selling of virtual item in the form of applications and online games. }\end{array}$ \\
\hline 4 & $\begin{array}{l}\text { Subscription-based } \\
\text { revenue }\end{array}$ & $\begin{array}{l}\text { In this business model, income is received from the subscription cost paid by the consumers for a digital content period- } \\
\text { ically. The digital content could be news, music streaming, video, etc. Payment is made on regular basis for the service } \\
\text { and maintenance of the application or software, including downloading anti-virus with regular updates from the } \\
\text { internet. }\end{array}$ \\
\hline 5 & Selling of services & $\begin{array}{l}\text { This business model includes the provisions of online services, such as online law consultation, financial services, consul- } \\
\text { tations, and digital travel agent. }\end{array}$ \\
\hline 6 & $\begin{array}{l}\text { Licensing content } \\
\text { and technology }\end{array}$ & $\begin{array}{l}\text { The services provided are more specified, such as content digital making, algorithm, special software, and artificial intelli- } \\
\text { gence technology content with a license. }\end{array}$ \\
\hline 7 & $\begin{array}{l}\text { Selling of users data } \\
\text { and customized } \\
\text { market research }\end{array}$ & $\begin{array}{l}\text { Anything related to the database selling, database analysis, telematics and data gained for research purposes, including } \\
\text { internet service provider (ISP). }\end{array}$ \\
\hline 8 & $\begin{array}{l}\text { "Hidden" fees and } \\
\text { loss leaders }\end{array}$ & $\begin{array}{l}\text { This is a traditional model. In this category, goods/services are sold at a lower price or for free, then the losses are covered } \\
\text { by selling the complementary goods/services. Prices of complementary goods/services are set higher to generate profit } \\
\text { for the provider. For example, online banking that offers a purchasing discount. }\end{array}$ \\
\hline
\end{tabular}

Source: OECD [6], cited from Inside Tax Ed. 38 [7].

current business pattern development, particularly in the digital business pattern.

Previously, the OECD in 2013 has identified four elements of Income Tax that needs to be monitored concerning the digital economic activities, in the context of erosion of the tax imposition [7]:

1. Minimizing taxation in the market country using schemes to avoid the taxable presence by maximizing the interaction through the internet, avoiding permanent establishment, and minimizing the allocated profit to the function, asset, and risk in the market country.

2. Avoiding withholding tax or reducing the imposed tax. This is usually done by exploiting the function of Double Tax Avoidance Agreement (DTA) to reduce the withholding tax rate, for example on royalties.

3. Any effort to lower the tax imposition in the country that receives the revenue, usually done by establishing intermediary companies in the country that gives tax facility and allocates the profit to the country where the intermediary companies are built.

4. Any effort made for lower tax imposition in the ultimate parent country by exploiting the weaknesses of Controlled Foreign Corporation regulation in the ultimate parent country.

Besides the taxation issue on business income (Corporate Income Tax), tax imposition on digital service consumption, where the service is generated in the foreign country also raise another problem. Following the destination principle of the value added tax imposition, the tax should be imposed in the place where goods/services are consumed. In reality, service delivery such as the making of digital content is conducted online through the internet, where parts of them originated from abroad. Therefore, it will be impossible for the foreigner to impose the consumption tax from the sale of product on cross-jurisdiction. Seeing this phenomenon, domestic digital service providers face competitive pressure from other digital content provider located in foreign country, since domestic service provider has to impose tax on the services the provide, it will make the price higher compare to that of foreigner services.

The existence of digital economic activities will increase the possibility of business operation restructuring to eliminate the tax burden in high tax country or optimize profit shifted into low tax country. BEPS Initiative warns that the business activities concerning the use/exploitation of Intellectual Property (IP) ownership that is transferable to the country with the lower tax rate need to paid attention. Those business changes should be responded equally from the tax authority, including in Indonesia whereas one of large market. This article is intended to examines several things with regard to the digital economy in Indonesia, among others changes in tax regulation, structure/institutional of tax organization, human resources who understand the pattern and development of digital business and have capability to formulate tax regulation suitable for the business pattern and information technology reliable in transforming the business of the tax organization in Indonesia.

\section{RESEARCH METHOD}

The research approach used in this research is a qualitative approach. A qualitative approach is an approach focusing on social phenomena that cannot be done in a conventional laboratory but must go into the field. This approach aims to provide understanding and interpretation of a social phenomenon through direct observation. One characteristic of qualitative approach is that it is not value-free, means that the research process can be influenced by various values and thought. Furthermore, the theory used in this approach is not the main central, but it is only as a basis for the framework for analysist purpose. Thus, theory is not the aim of research to be verified but it is only supporting in the analysis process when it comes down the field. 
This research was conducted in the period from January to May 2019 with the location of research at the Head Office of the Directorate General of Taxes (DGT). The election of the Directorate General of Tax's Head Office is the only choice of research location and the most important location when examining the change of the tax authorities related to cultural changes in facing the digital economic era. In terms of objectives, this research is descriptive research. Descriptive research is a research that describes the phenomenon in detail or social phenomenon. The purpose of this research is to describe the extent to which the transformation of has been carried out by the tax authorities to face digital economic. Data collection techniques are carried out using qualitative data collection techniques, through literature studies, documentation studies and in-depth interviews. The data collected consists of primary and secondary data. Primary data consists of interviews with key informants, while secondary data comes from various information publications by the Indonesian tax authorities, tax consultants and mass media.

This study uses a framework of thinking by taking the Indonesian tax authority, the Directorate General of Taxation as the object of research based on the consideration that this institution is engaged to collect state revenues from taxes, in which more than $70 \%$ of state revenues comes from taxation. The presence of the digital era has made business activities more dynamic, cannot be ring-fenced by country's jurisdiction and increasingly mobile. When the issue of digital economics is not yet widespread, tax institutions continue to be faced with increasing revenue targets every year. With the presence of the digital economy, it will be a new challenge for tax institutions to be able to collect sustainable revenue amid the challenges that have been there before.

\section{RESULTS}

OECD understands that these challenges are not only problems in developing countries. OECD, through BEPS Action Plan 1 recommends considerations pertaining to the changes of domestic tax regulation (Ernst \& Young, 2015)[8].

1. It needs to modify the definition and scope of permanent establishment in the context of the digital environment. Also, it needs to consider adopting the anti-fragmentation rule, particularly concerning the profit setting on business activities as a result of business fragmentation that becomes more common in the context of digital economic activities.

2. Modification on the definition of permanent establishment to minimize the artificial forms through the conclusion of contract arrangements.

3. It needs to change regulation pertaining to transfer pricing in the context of digital economic activities.

4. It need to modify Controlled Foreign Company (CFC) rules to minimize of business fragmentation.

\subsection{Tax Administration Transformation}

Successful institutional transformation should begin with the formulation of the clear target and strategy, followed by explicit key performance indicator. Thereby, the organization will be able to set priorities according to the target. This could also help the organization to calculate the number of resources that need to be invested to utilize the technology in coping with the digitalization and disruption era [9].

In the disruption era, the availability and use of data are the main important parts in business planning as they serve as a capital in making a prediction. Moreover, PricewaterhouseCoopers [10] stated that in the future, the availability of data, the use of artificial intelligent and various technological instruments will be an essential facilities to help in solving various taxation issues. This means the collected data is the basis to create various scenarios that have leverage effect in decision-making. This changing pattern is the result of the demand created by the current dynamic that needs to be responded by a transformation.

According to the survey conducted by PricewaterhouseCoopers (PwC)-Manufacturers Alliance for Productivity and Innovation (MAPI) in 2015, 80\% of the tax functions will proceed better and more effective if supported by technology and cross-unit integration within the tax authority organization. According to the survey by Tax Executive Institute (TEI) in 2011-2012, Corporate Tax Department (TEI) mentioned that the budget required to develop IT is approximately $5 \%$ of the total budget used by the tax authority. However, the $77 \%$ of the tax functions have not used technology or does not have implementation function design that utilises technology as the backbone.

The use of reliable and real-time data as the basis for activity planning is becoming crucial, whether from the multinational taxpayer's side or the tax authority. Several things require close attention from the tax authority and the taxpayers concerning the use of data optimization challenges as an instrument for activity planning.

a. The increasing needs for detailed information and transparency of particular business entity activities as an initiation to minimize tax avoidance potentials.

b. There is a possibility that information framented to several business entities locations. The ability to integrate information and transform it into a leverage during the planning activity pattern is required.

Furthermore, the OECD [11] in Forum on Tax Administration (FTA) highlighted that the institutional adaptation process in the current technology-driven era, needs to consider several things as follows as the basic thinking in transformation:

a. There is a need for a quick response along with the taxpayer expectations, that is to minimize face-to-face meeting and increasing the volume of digital-based services.

b. It is expected that the tax institutions to be more agile, responsive in coping with sudden changes.

c. It is expected that there is an assurance for organizational architectural management that supports the real-time service through collaborative platform, administration integration and simplification.

d. Adaptive tax pursuance compliance conducted by optimizing technology.

e. The availability of capable human resource and more developed data-driven and intelligent lead cultures. 
Institutional transformation by optimizing the use of technology will have an impact on the working process that means there will be parts of the business process to be eliminated or added. The digital transformation will affect several [12], that is:

a. Services with possible changes from manual-based into online-application-based.

b. Process; changes on working pattern and management performance of each unit in tax administration.

c. Working practice, the presence of a new culture in the organization that can be implemented through learning by doing continuously under observation of the management.

d. Technology, updates on the use of technology with maximum usable capacity.

e. The change of operation that enable cross-unit integration to operate, but still accountable in running each unit functions.

The changes as mentioned above are becoming crucial considering that in the future, the business entity will thrive to create data flow trend merely for tax planning through a more efficient process. The implementation of data flow will help the business entity to reflect their tax burden and its impact to the business economy of the entity, as well as the possible planning [10].

In transforming the business process where IT serves as the backbone, the government will have to encounter a number of challenges. The Institute for Fiscal Studies [13] described that those challenges include: (i) change in the form of transformation are not a simple one. It will create the dynamic in the institution so that efforts to slow it down will be required; (ii) a need for regulation that is integrated to the implementation rules, where both are not expected to negate each other; (iii) the ability to use IT devices optimally; (iv) the implementation of functions by using IT, which means there will be changes in working pattern and cultures; (v) creating a new working culture to support the transformation plan.

The challenges encountered by the tax authority from the environment will be more complex as depicted in Figure 1.

The figure above describes that the tax institution should adapt to the changes in its environment. The inability to adapt to the changes will have an impact on the capability of tax authority in collecting the tax. The ability to adapt to the environment also becomes part of

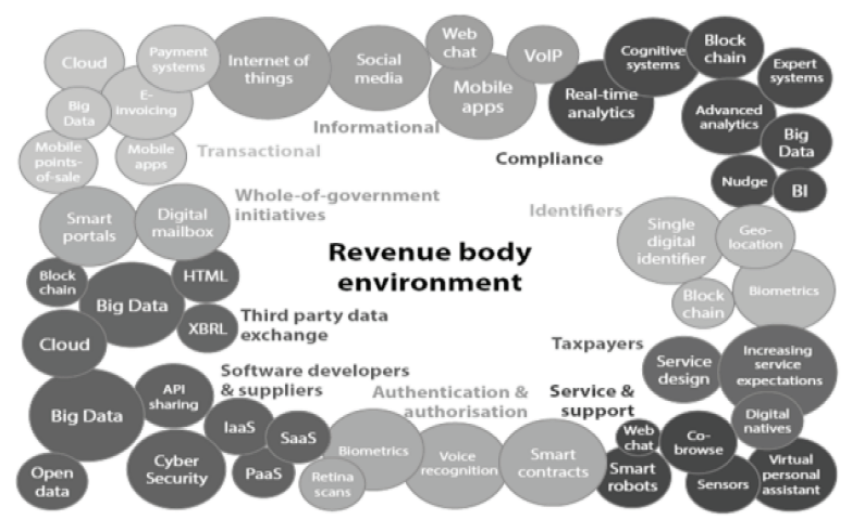

Figure 1 Disruptive environment affecting the tax authority of a country. Source: OECD [11]. the effort to increase revenue and requires an effort for investment, of which the IMF stated as the "luxury administration". The use of IT enables the tax institution to gather and process parts of the information to create more opportunities and collect the tax revenue efficiently. International Monetary Fund (IMF) [14] also mentioned that the investment on IT is a large and significant investment for the tax collection activities in this modern era. Consequently, the fund allocated for this activity should be monitored effectively.

Investment in technology is a good strategy. However, there are several questions as follows, to consider before the decision to use IT as part of the administration strategy is made [14].

1. What new things are expected by the tax administration from the new technology? Will there be automatization in data collection? Often, the tax administrator expects that the technology will give an instant result without understanding the things that they really need to achieve. It is a common thing that the budget for IT is an over-specify function because of the inability of the tax administrator to decide the suitable IT. When the mistakes occur, it creates a new complexity.

2. What things are actually needed by the tax authority in using the technology? To understand this will require an assessment pertaining to the expected goals. It is also closely related to the duties and functions, such as monitoring of the registration, tax reporting delivery, payment system, accounting system, audit,and collection. Understanding the basic environment that will be encountered by the tax officers along with their main tasks and functions should enable the tax organization to formulate the required technology.

3. Is the expected technology achievable from the budget perspective and who will allocate the budget? Generally, the cost of using technology is unlimited. It is the user that limits the cost according to their needs.

4. Who will provide the technology? The provider also needs to be considered for a long-term use of service.

5. How long the process of full capacity delivery and usage take place? Calculation of the expected target and the process of using the technology should also be done.

6. With the new system, could it efficiency be achieved? Technology is not the only motor to accelerate tax administration. It also requires support from human resource and other capable agents. This means the environment of the tax organization should also be in the same rhythm.

7. Who will be included if the tax administration is conducted under a new mechanism?

The use of IT is basically connected to the organization strategy, particularly in the formulation of expected outcomes. The use of IT is also a formulation of how targets will be achieved in a set period of time (subordinate plan). On the other hand, specifically, OECD [11] underlined a few things pertaining to the use of technology to optimize the tax administration implementation including various potential challenges encountered. In other situation, the presence of technology also contributes to supporting the emergence of various other products, services, and new business models that become additional new challenges for tax administrators. Therefore, this discussion is probably relevant in the context 
of tax administration in Indonesia as Indonesia is still striving to increase the tax compliance.

a. Technology disruptive era affects the economic activities pattern significantly. This indicates that the tax administrator will face the challenge to collect tax since a good understanding of the business activities pattern of an entity is required. On the other hand, the tax authority is also expected could provide technology-based service (digital-by-default) to the taxpayers. For the business, it not efficient to fulfill the tax obligations if they are not able to optimize technology use. The challenge encountered by the tax authority includes (i) the availability of reliable and sufficiently clear information concerning the tax obligations from the taxpayer in real time condition, including the online consultation, technology-based tax reporting form filling up, (ii) providing the online-based tax payment supported with the online payment confirmation and the availability of online form or tax calculator. This is expected to increase the taxpayer satisfaction to the provided services and the transparency.

b. The use of big data to track the business entity activities and monitor their business behaviours to generate various predictions and simulations. The big data serves as the source to do profiling for risk management purposes. Thereby, this will encourage the tax authority to always improve their capabilities and finally will lead to the new organizational culture, which is data-driven in formulating strategies and regulations. Finally, the changes in activity pattern will affect the organizational structure of the tax authority.

c. Tax service delivery by using digital services for filling up the tax reporting form, online payment, and confirmation, restitution tracking as well as other services supported by safety, reliable and accurate information storage. The implementation of such an administration system requires the proactive participation of the tax officers.

OECD [11] published the current administration trend where the tax authority does not only serve as tax collector institution, but also as an institution that provides service to the citizens. This concept is a new approach and an innovation in the modern era served as tax educational process for the citizens, which finally will increase the tax compliance. The expected compliance is at cooperative compliance level where the taxpayers have the will and ability to perform the disclosure of the fair tax information, reliable and valid which is, in the end, will be the basis in calculating the amount of tax burden paid to the government.

Generally, in reality, one of the main problems in developing countries pertaining to the tax administration issues are the lack of information in the form of a database, how the tax administrator could increase compliance, and how the data can be utilized. According to the research by Bird ([15]; p. 25) in several developing countries, generally around $90 \%$ of the government revenue from various taxes, only $10 \%$ is recorded from the tax reporting and the remaining $80 \%$ is still subject to the compliance issue. During the last decade, the use of technology is believed could increase the tax administration performances and the government's revenue. In developed countries, the tax administration institutional expenditure is sufficiently significant. Singapore allocates up to $40 \%$ tax collecting cost for the use of technology. The average fund allocated for technology penetration in developing countries are
Table 2 Tax ratio comparison to the allocated tax revenue with the use of information technology

\begin{tabular}{lcc}
\hline Country & $\begin{array}{c}\text { \% Tax revenue toward } \\
\text { GDP 2015 }\end{array}$ & $\begin{array}{c}\text { \% Cost of using technology } \\
\text { and communication toward } \\
\text { revenue 2015 }\end{array}$ \\
\hline Indonesia & 10.9 & 2.85 \\
Malaysia & 13.8 & 7.1 \\
Thailand & 19.1 & N/A \\
China & 18.9 & N/A \\
India & 9.7 & 7.95 \\
\hline
\end{tabular}

Source: Asian Development Bank [16].

ranging from $7 \%$ to $10 \%$. Several countries in ASEAN (Association of Southeast Asian Nations) allocates fund for technology differently in amount. Malaysia allocated on average 5.9\% fund for technology, The Philippines allocated $16.5 \%$, China allocated $9.1 \%$ and India $7.1 \%$ of the total cost for tax collection in 2010-2011. In 2010, Indonesia allocated $4.2 \%$ and 1.5\% in 2011 (Asian Development Bank [16]; p. 34). There is a tendency that a country with high tax ratio to have more attention on activities aimed to increase the tax compliance, such as the use of technology in the implementation of the tax administration system. Indonesia still has to work harder on several problems on how to increase the tax obligation compliance. This is depicted in Table 2 on tax ratio and allocated tax revenue by using technology.

In the case of using technology as the backbones in implementing tax administration activities, Indonesia is still far behind, compared with other countries. Considering the tax revenue is very vital to the Indonesian national budget, the government should already consider how to utilize technology as the backbone by performing initial assessment of the needs along with the expected outcomes.

\subsection{Strengthening the Institutional Capacity, Human Resources of the Tax Institution}

The successful transformation of tax administration is determined by the supports from investment on strengthening human resource capacity that should be done continuously to create a new ecosystem and cultures. It is expected that the new learning organization culture will emerge, where each individual is equipped with appropriate skills/competence, suitable to their professional field. The new learning culture will also become a new organization culture since each individual has leverage and insight when it is given a problem to solve. The creation of a new culture requires a flexible hierarchical communication line. In addition, the new modern organization culture also allows each individual to work independently and take the initiative by using the available technology [17].

Dealing with the digital era, the tax administrator particularly the ones who directly connected to the taxpayers, not only should have a deep understanding on the positive law in a particular country but also need to have skills on the following aspects ([9]; p. 14):

a. Ability to understand and design complex scenario from various sources of data/information for early detection of the possible tax avoidance practices while maintaining the compliance of the taxpayers.

b. Good ability to analyze data for effective, efficient and transparent auditing implementation, as well as consolidation. 


\section{DISCUSSION: HOW THE INDONESIAN TAX REGULATION AND TAX INSTITUTIONAL TRANSFORMATION DEALING WITH DIGITAL ECONOMY ERA?}

\subsection{The Dynamic of Tax Regulation Changes}

In general, the government of Indonesia has realized that the digital economic activities have increased and will keep growing exponentially. The government of Indonesia through The Ministry of Communication and Informatics has captured this opportunity by publishing a Circular Letter No. 3 year of 2016 concerning Internetbased Application and/or Content Service Delivery (over the top) [18]. The letter described various economic activities, categorized as application and/or digital content services.

According to the circular letter, application and/or digital content delivery through the internet includes: (i) Application services through internet that is the utilisation of telecommunication services through protocol-based telecommunication network to enable communication services in the form of short text message, voice call, video call and chatting, financial and commercial transactions, data storage and downloading, games, social media and networking, and other derivatives, (ii) Content service through the internet that is any form of digital information delivery, i.e. writings, voices, pictures, animations, music, video, film, games or combinations of parts and/or all of that have been mentioned, including in the form of streaming or download by utilising the telecommunication services through internet protocol-based telecommunication networks, (iii) application and/or content service delivery through the internet, which later known as Over the Top Service, which is application through internet service and/or content service delivery through internet.

Furthermore, from the circular letter, it is also mentioned that concerning the business organization performing the digital economic activities, that is the Over the Top Service, could be delivered by the individual or foreign business organization and bound with compulsory terms to have a permanent establishment in Indonesia. The permanent establishment is built according to the applicable tax regulations. The circular letter was published in response to the various phenomenon of the massive emergences of over the top service providers that are mostly big companies such as Facebook, Twitter, Google, and Yahoo. These companies do not have a permanent establishment in Indonesia but actively run their business activities and generate significant profit in Indonesia. However, the intention of the Ministry of Communication and Informatics to require permanent establishment development is not specifically aimed for taxation purposes, but to fulfill the aspect of consumer protection, particularly the information protection gathered by digital economic business agents [19].

In reality, the obligation to develop permanent establishment has not been regulated comprehensively in any Indonesian tax regulation, thus making its implementation unclear. The obligation to develop permanent establishment is confirmed through a Circular Letter published by Directorate General of Taxes No. SE-04/PJ/2017 [20] concerning the Permanent Establishment Development for Foreign Tax Subject that provides the Application Service and/or Content Service through the Internet. The Confirmation Letter serves as guidelines for the working units in the DGT environment concerning the permanent establishment for Foreign Tax Subject that provides Over the Top Service in Indonesia. However, the circular letter only serves as a confirmation, thus making anything described on the letter is insufficiently significant to be available on the regulation of digital economic activities of over the top service providers. To this moment, over the top service providers have representative offices in Indonesia.

In fact, enforcing digital economic activities agents to create the permanent establishment for Over the Top Service providers without changing the Income-tax regulation should not be done as it will have an impact to the government's credibility. Nevertheless, it is understandable that the government intention is to promote fairness between domestic and foreign country business agents, in the context of an equal level playing field. This condition is exacerbated by the limited access for the tax authority toward the transaction data, thus creating a new challenge of managing the administration. Moreover, the law product that is only in the form of the circular letter does not have a strong legal basis to regulate the issue.

Understanding that the digital economic activities have significant future prospects, the government releases regulation on digital economic activities roadmap, particularly on e-commerce activities. The regulation is released by the President in the form of E-commerce Road Map to promote expansion and increase the citizens' economic activities in Indonesia efficiently and widely connected. The e-commerce roadmap could also encourage creation, innovation, and invention of new economic activities between young generations. The Coordinating Ministry for Economic Affairs [21] also stated that the initiative is aimed to provide certainty and easy access to economic activities using e-commerce by providing directions and strategic guidelines to accelerate Electronic-based National Commerce System in 2016-2019. The e-commerce roadmap regulation is a form of prioritizing and protection to the small and medium national enterprises, particularly start-up business agents.

The economic regulation package XIV on E-commerce Road Map which is described in Presidential Regulation No. 74 the year of 2017 [22], covers eight aspects of regulation, namely:

1. Finance in the form of: (1) Credit for poor Kredit Usaha Rakyat (KUR) ${ }^{1}$ for platform developer tenant; (2) grants for start-up counterpart business incubator; (3) Universal Service Obligation (USO) fund for small and medium enterprises and start-up e-commerce platform; (4) angel capital; (5) seed capital from foster parent; (6) crowd-funding.

2. Tax in the form of: (1) tax deduction for local investor investing in start-up business; (2) tax permit/procedures simplification for e-commerce start-up with under 4.8 billion turnovers per year; and (3) same tax treatment to the e-commerce businessmen.

3. Consumer protection; through (1) Government regulation on Electronic-based commerce transaction; (2) harmonization of the regulation; (3) commerce payment system and government goods/services expenditure through e-commerce; and (4) gradual national payment gateway development.

4. Education and human resource; covering: (1) e-commerce awareness campaign; (2) national incubator program; (3) e-commerce

${ }^{1}$ Kredit Usaha Rakyat is a financial credit program created by Indonesian government to support micro-scale business. 
curriculum; and (4) consumer, entrepreneurs and law enforcer education on e-commerce.

5. Logistics; through: (1) the use of National Logistics System (Sislognas); (2) strengthening the local/national courier companies; (3) small and medium enterprises logistic data shifting development; and (4) logistic development from rural to urban areas.

6. Communication infrastructure, through the establishment of the broadband network.

7. Cyber security: (1) composing national monitoring system model for e-commerce transaction; (2) public awareness of cybercrime, and (3) arranging SOP concerning the consumer data storage and safety certification.

8. Operating management development; through monitoring and evaluation of e-commerce roadmap implementation.

Pertaining to the tax aspect on the transaction conducted by e-commerce entrepreneurs, to this moment the government is still under discussion to decide a taxation format that will highly promote fairness to all small and medium enterprises without adding more administrative burden so that the domestic e-commerce business could grow better. Various initiatives emerge, for example, an idea to impose $0.5 \%$ final tax of the total transaction collected by marketplace agent, where the e-commerce agents resided. In this case, the expected regulation should understand the rapid dynamic of the business and be sensitive to any regulation that could distort the economic activities. From the discussion above, there is an indication that the digital economic activities growth has not created a landscape of new taxation regulation in Indonesia. On the other hand, the Indonesian tax regulation has not yet transformed to follow the current rapid business dynamic.

\subsection{Organizational Transformation}

Confronting the digital economic activities, government organization such as tax authority is expected to provide balanced responses. Ismail [23] in his book Exponential Organization (ExO) emphasized that it is essential to abandon the traditional culture and pattern and move forward to an ExO for surviving the current disruption era. Such traditional approach is indicated by the practice of maintaining the use of linear pattern in solving the problems of various activities. In an $\mathrm{ExO}$, the development of the organization is conducted by optimizing the resources that should not be owned by the organization. In other words, focuses on the efficiency by optimizing data as the main asset and the capital to achieve transformation using the optimal technology. The organization is developed as a dynamic institution, responsive to the external environment uncertainty. This value changes the working pattern (engagement) of the organization to become agiler.

Although Ismail described that changes are very important for private sector organization, the concept can also be adopted by the public sector organization, considering the economy dynamic as a result of the disruption era which also influences the public sector organization. The tax authority is a public sector organization that has high complexity. Gunadi [24] mentioned that the emergence of various types and form of business, various bilateral, multilateral and global agreements become a great challenge encountered by the tax authority when implementing their functions. Understanding this complexity becomes a challenge and factor that facilitates the cultural change of the tax administration in the current disruption era.

Previously, a research conducted by Nurmantu [25,26] stated that there are four cultural change phases in Indonesian tax authority organization of the DGT. In the first phase (1983/1984) before the early reform, the values were based on superiority in estimating the tax burden where the taxpayers were more inferior. In the second phase (1983-1994 reformation), there was a change in the superiority position of the tax officers, but the tax obligation investigation was not based on the fairness principle and the service provided to the taxpayers was not based on the values of good service. Moreover, there was an autocracy value in the form of tax regulation that was not fully supported by tax philosophical aspect and law, and occasionally disregarding the fairness principle in achieving the targeted revenue.

During the third phase (1995-2000 reformation), the DGT started to realize the importance of good service to the taxpayers, despite the old culture that still remains. In this phase, the leader of the DGT started to realize the needs for running their core business more efficiently. Several artefacts were created during this phase, including the jargon of "know your taxpayer!" The fourth phase (2000-2008) $[25,26]$ the DGT was introduced to the new standardized service culture. It is reflected on various publication products, such as a line saying "committed to best service and high standard". Despite the cultural changes that occurred during those phases, the service provided to the citizens is still considered lacking because it has not been the priority and preference of most DGT officers. The development of espouses value to become the basic common underlying assumption until the fourth phase transformation era is considered insufficient.

At this moment, entering the digital era presented with the shifting of business activities pattern becomes a new challenge and opportunity for the government. The DGT is expected to be able to respond the changes and initiate a transformation to increase the human resource quality, supported by the cultural change in organization and leadership, institutional structure, core-business working pattern as well as optimal use of technology. The Ministry of Finance re-arranged the reformation team described in the Decree of Ministry of Finance No. KMK-885/KMK.03/2016 [27] that is aimed to improve the structural organization and human resource quality, to optimize IT and database gathering concerning the business transformation and the quality improvement of the legislation. This expectation will create a new culture to improve the taxpayers' trust to the tax institution, taxpayer compliance, reliability of tax administration management, as well as the integrity and productivity of the tax officers. The improvement program was formulated on the DGT Institutional Transformation Program Initiatives as shown in Table 3.

The initiatives mentioned above reveals that the DGT has realized the needs for cultural changes, that becomes the foundation to perform the tax collecting missions and functions as budgeter (to collect government's revenue from tax) and regulerend (to use the tax as a social and economic engineering instrument). It is conducted through professional and efficient works, which is articulated into nine visions and further described several forms of initiatives and objectives. Dealing with the digital era, the initiatives, that are the elucidation of the new culture, indicate the needs for a particular 
Table 3 Directorate General of Taxes (DGT) institutional transformation program initiatives

\begin{tabular}{|c|c|c|}
\hline No. & Mission & Initiative \\
\hline \multirow[t]{2}{*}{1} & All taxpayers & $\begin{array}{l}\text { Segmentation and coverage model. } \\
\text { To reach the informal economy } \\
\text { through end-to-end approach. }\end{array}$ \\
\hline & & $\begin{array}{l}\text { To improve the VAT administration } \\
\text { system. }\end{array}$ \\
\hline 2 & $\begin{array}{l}\text { Maintaining the } \\
\text { risk-based } \\
\text { compliance }\end{array}$ & $\begin{array}{l}\text { To develop a predictive, risk-based } \\
\text { compliance model pertaining to } \\
\text { the business model. } \\
\text { To increase the effectiveness of } \\
\text { investigation and collection. }\end{array}$ \\
\hline
\end{tabular}

3 Improving law enforcers integrity
To ensure the quality of law enforcers consistency.

Achieving indirect benefit through integrated communication

Strengthening the external partnership

Implementing the 'learn' operation and end-toend electrification

Shifting to the multichannel service model

Strengthening the human capital organization for data gathering, law enforcement and reaching out the taxpayers.

a. To improve the Tax Service Office.

b. To expand effectively the coverage of Data Processing Center (DPC) and improve the capability for data capturing.

a. To increase the capacity of call center significantly functionality.

To re-harmonize the functional staff and selectively improve their capacity.

a. To restructure the organization.

\section{Objective}

Segmentation and coverage model.

To access the informal economy by prioritizing the informal sector with highest tax potential and coordinate the end-to-end approach in all DGT regional offices.

To optimize revenue from the VAT by increasing compliance.

To ensure the DGT achieve their strategic objectives by facilitating the management for better decision making.

To increase audit coverage ratio, reduce the total investigation duration and improve the effectiveness of collection while targeting the tax-dodger more effectively.

a. To arrange the internal compliance process which has target and standard, to improve quality and minimize variations in the law enforcement process.

b. To ensure information and treatment consistency in every inspection, early examination, objections, appeal, and investigation.

To publish communication strategy. a. To increase compliance by giving counselling to the taxpayers and publishing the tax enforcement.

b. To improve the image of the DGT through communication on transformation implementation and proactively manage the existing issues.

To include the third party systematically To build and strengthen the external partnership in data distribution, reaching out taxpayers, and law enforcement as an effort to increase the revenue and compliance.

a. To run the transformation service frontline in the Tax Office.

b. To promote efficiency in document processing system by implementing the learning principle in the Tax Office.

b. To expand the website's

b. To ensure the autonomy required for transformation. a. To expand the role of DPC in supporting the document digitalization in the DGT.

b. To improve speed, accuracy and safety of the tax reporting process.

To develop the contact center that provides multi-channel access with various services equipped with bilingual languages, integration to the website of the DGT and outbound capacity.

a. To develop a website that is user-friendly, fast and easy to access.

b. To improve/increase the service features and counselling.

a. To clarify the functional roles of AR and design the roles or sections to handle the function service or investigation.

b. To identify the special needs for higher capacity and ways to improve the functional roles selectively

a. To introduce $1 \mathrm{~B}$ echelon screen to reduce the span of control.

b. To aggregate the similar functions (for example, transformation unit) and introduce the new unit for expected capability (for example, business intelligent, quality assurance)

a. To selectively negotiate flexibility of human resource aspect, organization, and budget.

b. To request for an agreement so that the DGT could become a semi-autonomous institution

Source: Insiatif Program Transformasi Kelembagaan Tema Perpajakan. DGT, The Ministry of Finance Republic of Indonesia [28].

strategy to reach the taxpayers. This includes the audit strategy, law enforcement consistency, collaboration with various other institutions concerning the data gathering, optimal use of IT and how IT can be used as the backbones in running the DGT core business. Moreover, the human resource quality improvement in the DGT also becomes one of the agenda in the initiatives along with the strengthening organizational structure.

These objectives are possible to achieve if translated into various programs with measurable outcomes led by people with outstanding leadership skills. Tax Monitoring Committee (KomwasPajak) [29] underlined that the biggest challenge for each DGT organization leader is the consistency to run the tax collecting that should be based on the fairness principle for the taxpayers (between large taxpayers, small entrepreneur taxpayers, or individual taxpayers) and the tax officers in achieving the targeted revenue. On the other hand, Apindo [30] observed that the leadership quality of the DGT has gradually improved. However, transparency is still required, particularly concerning the input delivery from the entrepreneurs and citizens.

Looking back at the DGT reformation paths, in general, there has been a change in organizational culture occurring incrementally. It requires continuous monitoring and evaluation to ensure that the expected organizational culture to penetrate more to become a shared value in the organization and a basis for daily attitudes. The simplest proxy that can be used to evaluate organizational 
culture changes and leadership besides the tax ratio as a quantitative parameter is the level of positive perceptions of the taxpayers to the DGT performance. To this moment, the citizens' perceptions to the performance of DJP, revealed by various researches [31-33] shows that various efforts are still needed to improve the citizens' trust.

\section{CONCLUSION}

The economic activities pattern is growing and moving exponentially and very dynamic that changes in regulation and institutional aspects are essential. Various international organizations have provided guidelines and reminders concerning this issue since the absence of proportional responses and changes in traditional patterns will create disruption to the economic activities. In the context of regulations, there has been a shift in taxation and fairness concepts, which will be derived into various regulations, followed by the tax authority transformation as the tax administrator institution. Currently, the human resource capacity improvement of the tax authority is very crucial in keeping up with the business development, along with the optimal use of information technology in each working line.

The government of Indonesia also fully realizes that the rapid development of the economic activities and respond it by publishing various regulations and initiatives. However, some of the regulations are still insufficient to respond to the existing challenges. This indicates that in reality, the government is still unable to respond to the current dynamic properly and proportionally. Therefore, more comprehensive improvement through engagement of various economy agents to properly respond to the current economic development is essentially required.

\section{CONFLICTS OF INTEREST}

The authors declare they have no conflicts of interest.

\section{AUTHORS' CONTRIBUTION}

This article contributes to the study on the changing of government behaviour driven by technology advancement, specifically for tax authority. The authors aim to describe and explain how the tax authority reacts to adjust the organization structure, the regulation and human resource capacity to catch-up the digital business transformation due to technology advancement.

\section{ACKNOWLEDGEMENTS}

The author would like to thank for Dr. Edi Slamet Irianto (Head of Jakarta Regional Tax Office and Senior Lecturer on Graduate Program Faculty of Administrative Science Universitas Indonesia) for the input and comments on the process of writing of this research report.

\section{REFERENCES}

[1] M. Olbert, C. Spengel, International taxation in the digital economy: challenge accepted?, World Tax. J. 9 (2017), 3-45.
[2] European Parliament, Tax challenges in the digital economy, study for the TAXE 2 committee, 2016. Retrieved from: https:// www.europarl.europa.eu/thinktank/en/document.html?reference=IPOL_STU(2016)579002 (accessed March 3, 2018).

[3] OECD Observer, Tax challenges, disruption and the digital economy, 2016. Retrieved from http://oecdobserver.org/news/ fullstory.php/aid/5600/Tax_challenges,_disruption_and_the_ digital_economy.html (accessed March 3, 2018).

[4] D. Leipziger, W. Dodev, Disruptive technologies and their implications for economic policy: some preliminary observations, Institute for International Economic Policy Working Paper Series, Elliott School of International Affairs, The George Washington University IIEP-WP-2016-13, Washington, 2016.

[5] W. Schön, Ten questions about why and how to tax the digitalized economy, Working Paper of the Max Planck Institute for Tax Law and Public Finance No. 2017-11, 2017, pp. 1-29.

[6] OECD, Addressing the Tax Challenges of the Digital Economy, Action 1-2015 Final Report, OECD Publishing, Paris, 2015.

[7] Inside Tax Edisi 38, Aksi BEPS: Menangkal Penggerusan Basis Pajak, Danny Darussalam Tax Center, Jakarta, Indonesia, 2016.

[8] Ernst \& Young LLP, Tax Insight for Business Leader No. 14, EYGS LLP, United Kingdom, 2015.

[9] Microsoft and PricewaterhouseCoopers, The data intelligent tax administration: meeting the challenges of big tax data and analytics, 2018. Retrieved from: https://www.pwc.nl/nl/assets/documents/the-data-intelligent-tax-administration-whitepaper.pdf (accessed March 6, 2018).

[10] PricewaterhouseCoopers, Unlocking the power of data and analytics, PricewaterhouseCoopers, London, United Kingdom, 2015.

[11] OECD, Technologies for better tax administration: a practical guide for revenue bodies, OECD Publishing, Paris, 2016.

[12] E. Andrews, D. Thornton, J. Owen, A. Bleasdale, G. Freeguard, I. Stelk, Making a success of digital government, Institute for Government, London, UK, 2016.

[13] The Institute for Fiscal Studies, Improving tax policy making emerging findings - an invitation to comment, 2016. Retrieved from: https://www.instituteforgovernment.org.uk/sites/default/ files/publications/Post-roundtable \%20paper\%20FINAL $\% 20$ FINAL.pdf (accessed April 1, 2018).

[14] IMF Technical Notes and Manuals, Use of Technology in Tax Administration 2: Core Information Technology Systems in Tax Administrations, Fiscal Affairs Department, 2017.

[15] R.M. Bird, Improving tax administration in developing countries, J. Tax. Admin. 1 (2015), 23-38.

[16] Asian Development Bank, A comparative analysis of tax administration in Asia and the Pacific, 2014. Retrieved from: https:// www.adb.org/sites/default/files/publication/41792/tax-administration-asia-pacific.pdf (accessed March 20, 2018).

[17] E.H. Schein, Organization Culture and Leadership, Jossey-Bass Business \& Management Series, San Francisco, 2013.

[18] Circular Letter No. 3 year of 2016 concerning Internet-based Application and/or Content Service Delivery (over the top).

[19] Y.H. Widiartanto, Menkominfo Keluarkan Aturan untuk TI Asing, 2016. Retrieved from: https://tekno.kompas.com/ $\mathrm{read} / 2016 / 04 / 01 / 11211497 /$ Menkominfo.Keluarkan.Aturan. untuk.Perusahaan.TI.Asing (accessed April 9, 2018).

[20] Directorate General of Taxes No. SE-04/PJ/2017 concerning the Permanent Establishment Development for Foreign Tax Subject that provides the Application Service and/or Content Service through the Internet. 
[21] The Coordinating Ministry for Economic Affairs, Paket Kebijakan Ekonomi XIV: Peta Jalan e-Commerce, 2017. Retrieved from: https:// www.ekon.go.id/berita/view/paket-kebijakan-ekonomi-xiv.2859. html (accessed April 9, 2018).

[22] Presidential Regulation No. 74 the year of 2017 concerning e-Commerce Roadmap

[23] S. Ismail, Exponential organization: why new organization are ten times better, faster and cheaper than yours?, Singularity University Diversion Publishing, Canada, 2014.

[24] Gunadi, Reformasi Administrasi Perpajakan dalam Rangka Kontribusi Menuju Good Governance, Professorship Speech, FISIP Universitas Indonesia, Depok, Indonesia, 2004.

[25] S. Nurmantu, Dampak Faktor-faktor Nilai Budaya Organisasi terhadap Kualitas Pelayanan Perpajakan sebagai Suatu Kinerja Studi Pada Kantor Wilayah WP Besar Direktorat Jenderal Pajak, Disertasi, Program Pasca Sarjana FISIP UI, Depok, Indonesia, 2008.

[26] S. Nurmantu, Budaya. Organisaasi, I. Dari Chester Banard ke Michael E. Porter, Departemen Ilmu Administrasi FISIP UI, 2008.

[27] Decree of Ministry of Finance No. KMK-885/KMK.03/2016 concerning Establishment of Team for Indonesia Taxation System Reform.
[28] The Ministry of Finance Republic of Indonesia, Jakarta, Indonesia, 2017.

[29] Hukum. Online, Tantangan Dirjen Pajak Mendatang, 2014. Retrieved from: https://www.hukumonline.com/berita/baca/ lt54897d825d59c/ini-tantangan-dirjen-pajak-mendatang (accessed April 9, 2018).

[30] Nasional. Kontan, Ini Komentar Pengusaha Soal Kinerja Dirjen Pajak, 2017. Retrieved from: https://nasional.kontan.co.id/news/ ini-komentar-pengusaha-soal-kinerja-dirjen-pajak (accessed 04 April 2018).

[31] A.U. Hadini, D. Lituhayu, H. Lestari, Perubahan Sistem Organisasi Perpajakan di Kantor Direktorat Jenderal Pajak Studi Kasus Kantor Pelayanan Pajak Pratama Semarang Gayamsari, Indonesia J. Public Policy Manage. Rev. (2012), 41-50.

[32] N. Yusmita, Perspesi Masyarakat terhadap Kinerja Direktorat Jenderal Pajak, Research Report, Jakarta, Indonesia, 2015. Retrieved from https://idr.uin-antasari.ac.id/266/.

[33] I.N. Widia, Mengubah Paradigma Masyarakat terhadap Pajak, Ketua Lembaga Edukasi dan Advokasi Pajak, Investor Daily, Indonesia, 2017. Retrieved from https://investor.id/opinion/ mengubah-paradigma-masyarakat-terhadap-pajak. 